\title{
Challenging Hegemonic Masculinity, Pursuing Gender Equity: Case Study of Male Muslim Leaders of Islamic Boarding Schools
}

\section{Edi Hayat}

\begin{abstract}
This article is about men's role in promoting gender equity with case study of male Muslim leaders of Islamic boarding schools who involved in the mainstreaming of gender equity. Few of them, who have engaged in, have been playing an effective role in gender mainstreaming. They can challenge the root causes of gender inequity without being seen to disrupt the socio-cultural and religious setup. They understand the gender-biased cultural practices necessitate to be changed and have the capacity to intervene in those aspects of social construction considered inimical to gender equity. Besides, they have empowered personally because they have made gender equity as their strategic choice to be pursued. Although they have previously denied choosing the issue, they have gradually received it fully in their preoccupation. Their empowerment has consisted of three dimensions, tangible and intangible resources, agencies, and the power of achievement. Their effectiveness has additionally depended on their vantage point as leaders, to tackle the root causes rather than the symptoms of gender inequity. In this paper, I look in detail at their work and explore the lessons that can be taken and replicated elsewhere in the Islamic world for greater gender equity.
\end{abstract}

\section{Keywords}

Masculinity; agency; empowerment; gender equity; male Muslim leader

\section{Introduction}

In recent years, the concern of men's involvement in promoting gender equity has been on the increase. This is demonstrated by the ever increasing programs and studies being conducted which are concerned with masculinity and gender relations in development (Kimmel et al. 2005, 1; Ruxton 2004, 3). Gender inequity is not exclusively a matter of women but a matter of human rights worthy of attention by every person that such a broad involvement is necessary.

Edi Hayat is an expert staff at Commission VIII of the House of Representatives of the Republic of Indonesia (DPR RI). He completed a Masters of Arts in Sustainable International Development at the Heller School for Social Policy and Management, Brandeis University, United States.

\section{Corresponding Author:}

Edi Hayat, Commission VIII of the House of Representatives of the Republic of Indonesia, Jakarta, Indonesia.

Email: edihayat10@gmail.com 
The pursuit of gender equity requires strategy, commitment and hard work. Men and women should work together to achieve the desired gender equity. Measuring men's involvement in gender equity is very important, but there seems to be a limitation on specific literature discussing this issue. Even though available literature discuss on how to measure empowerment, they seldom venture toward discussing what this amounts to when masculinity is the variable in question. I will in this paper consider men who have been involved in gender equity to have acquired the threshold of empowered men.

Since the concern of Gender and Development (GAD) ${ }^{1}$ is how to tackle the root causes of gender inequity, it provides a real opportunity for men's involvement in promoting gender equity. The importance of men's involvement in promoting gender equity was officially declared at the fourth United Nations Conference on Women in Beijing, China, 4-15 September 1995. The declaration of the Beijing Platform for Action, explicitly insisted that all governments around the world should involve men in any activity aimed at realizing gender equity. Declaration number 25 stipulated that men have to be fully encouraged in all actions toward gender equity (Nations 1996, 4). This article will analyze men (male Muslim leaders or Kiai) who have been involved in efforts to pursue gender equity. More specifically, I would like to discuss how male Muslim leaders of Islamic boarding schools (pesantren) play an effective role in realizing gender equity. This question is based on the reality that few male Muslim leaders of Islamic boarding schools in Java, for example, have been involved in any activity pursuing gender equity. This paper argues that male Muslim leaders have been playing a productive role in gender mainstreaming, they can challenge the root causes of gender inequity without being seen to disrupt the socio-cultural and religious setup.

My analysis proceeds as follows. After a summary review on masculinity as social construction, and possible mechanism of how to measure men's involvement in gender equity, I would like to present my case study. Firstly, I will discuss Islam, masculinity, and male leaders of Islamic boarding schools. Masculinity as a social construction is also under questioning and critique in the Islamic context. The identity of masculinity is an arena of contestation between the conservative perspective and the progressive perspective. The progressive perspective challenges the established conservative perspective of masculinity that

${ }^{1}$ GAD emerged and replaced Women in Development (WID) as the desired paradigm for addressing gender inequity. WID had several weaknesses, including; women were just perceived as the beneficiaries of development and were, therefore, to be integrated into development as the problem needing targeted inclusion in development. WID did not tackle the main cause constituting unequal relationship between men and women, namely the discrimination of women in the political, social, and cultural structure (Young 1997, 51-52). GAD viewed development as a complex process that included the totality of social, political, economic, and cultural improvement in the development context. Therefore GAD consists of three approaches, namely, changing from women to gender and unequal relations between men and women; tackling the root cause of gender inequity by re-examining social, political, economic, and cultural structure discriminating and marginalizing women; the achievement of gender equity by the realization of transformative change from inequitable to equitable relationships between men and women (Greig 2000, 1). 
emphasizes a single identity of masculinity, namely the superiority of men over women. Following on progressive perspective, some male Muslim leaders get involved in promoting gender equity. Secondly, I will look in detail at their work in involving gender equity advocacy based on their strategic choice of life. As we know, empowerment is about enhancing people's freedom of choices and actions to guide their own life. They are considered as "empowered persons". Three dimensions should be taken into consideration in assessing their empowerment, including resources, agency, and achievement.

\section{Literature Review}

\section{Masculinity as Social Construction}

Many studies have been conducted focusing on masculinity. Tim Edwards (2006), however, classifies the studies of masculinity into three phases or waves. The first wave of the study of masculinity, the 1970s, concerns questioning masculinity its self. Such gender, masculinity is socially constructed, not static, depending on the local context where the social construction of masculinity takes place (Edwards 2006, 2). As a social construction, masculinity can be defined as social roles, behaviors, and practices imposed on men in a given society and social context (Nyerere 2007, 1). The definition emphasizing masculinity as a social construction offers ways to rethink the social roles driven to men (Greig 2000,5). It is because the existing social roles of men usually refer to the construction based on Western culture. The social roles supposed to be played out by men and based on Western culture are for instance independent, heterosexual, aggressive, competitive, educated, physically strong, and so on (Howson 2006, 60). The social roles, nevertheless, cannot be generalized and imposed on all men throughout the world (Connell 2005, 71; Howson 2006, 60), because of the fluidity and variability of cultural and social experiences constituting across the globe.

The second phase of the study of masculinity, the 1980s, continues the question and criticism of the first wave that focused on the social construction of masculinity and its strong imposition of a certain behavior to men. The second phase goes beyond that, introducing the complexity of masculinity and its application in the field, which is strongly related to power. Masculinity is seen to be concerned with the discourse of power and how power is maintained. The relation of power within masculinities determines what kind of masculinity controls and oppresses over the other masculinities (Edwards 2006, 2). The prominent figures of the second wave of masculinity are R.W. Connell, a Professor of Education at the University of Sydney in Australia, and R. Howson, a Lecturer in Social Theory, Gender, and Social Policy at the University of Wollongong, in Australia as well. Both develop the complexity of masculinity and its operation, encompassing hegemonic masculinity, complicit masculinity, subordinate masculinity, and marginalized masculinity (Connell 2005, 76; Howson 2006, 59).

Hegemonic masculinity refers to the configuration of gender practices privileging men, subordinating women, and it has been socially accepted to maintain the dominant position of men toward women (Connell 2005, 77; Howson 
$2006,60)$. So hegemonic masculinity is the idealized characteristics of men based on Western cultures as mentioned earlier. The category of complicit masculinity refers to men taking benefits from the patriarchal social system, however, they appreciate interchangeably social roles between men and women, for example, the role of breadwinner. Additionally, they never perpetrate any form of violence against women (physical and psychological violence). Thus, although the men take benefits from the patriarchal social system, it does not impede them to become the defenders of gender equity. Therefore, they are supposed to be protesters of hegemonic masculinity (Connell 2005, 79; Howson 2006, 65).

Subordinate masculinity refers to men having different sexual orientations from men in general, such as men who tend to homosexuality rather than heterosexuality. Thus, homosexual men are subordinate to the dominant culture of heterosexuality prevailing among men in general (Connell 2005, 78; Howson 2006,62 ). The practices of homosexuality probably can be found in every group of society. But the differences among them are the levels of their openness. In contemporary European and American societies, they are open and mutually respect their sexual orientation. Even in some countries such as in the Netherlands, homosexual couple marriage has been legalized (Connell 2005, 78). The practices of homosexuality in Islamic society for example, nevertheless, is closed, because Islamic teachings ban homosexuality which the perpetrators punished a great sin and condemnation. Therefore, Muslims practicing homosexuality will be feeling a psychological conflict. On one hand, their sexual orientations tend to homosexuality, while on the other hand, the Islamic teachings that they believe in forbidding it (Siraj 2006, 202, 205). The variants of masculinity are mostly based upon gender order. Those of marginalized masculinity are based upon the interplay of gender with other social structures such as ethnicity, class, race, and skin color. For example, men from the upper class marginalize men from the lower class out of their feeling for a sense of entitled hegemony over the others (Connell 2005, 80; Howson 2006, 63-65).

The third wave of study of masculinity is influenced by post-structural theory especially related to questions of normativity, performativity, and sexuality (Edwards 2006, 3). The third wave tries to question and blur the single imposition of masculinity. There is no single identity of masculinity that can label men. Men are subjects probably attached with multiple identities of masculinity. Men are dynamic and active subjects who can constitute themselves where they take place. When constituting themselves, men can become mad subjects, questioning and even deconstructing what is perceived as the normal or standard identity of masculinity. The normal or standard identity of masculinity is established because of historical processes regulating, attaching specific meaning, and even reproducing as the truth of masculinity. So, as the result of historical processes, the normal and standard masculinity incredibly opens to be changed because of historical processes as well (Pini 2008, 5). An example of the normal and standard masculinity changing because of historical processes is the men's role of breadwinner, which changes because of industrialization. It provides for the feminization of labor markets enabling women to come into paid works and earn 
income. The feminization of labor markets challenges the role of breadwinner usually attached to men (Kabeer 2007, 3).

\section{Men's Involvement in Gender Equity: Measurement}

The measurement of empowerment at the individual level has been developed by Naila Kabeer (2001), a researcher of the Institute of Development Studies, at Sussex University, United Kingdom (UK). The notion of empowerment refers to "the ability to make strategic choices of life in the context where the choices are previously denied" (Kabeer 2001, 19). There are dimensions of empowerment that should be measured, including resources, agency, and achievements. The three dimensions are interrelated, cannot be separated from each other because of their tightly mutual interdependence. The successful change of each dimension will contribute to the success of the other changes. The notion of resources refers to a condition constituting the choices that are made; agency is "a process by which the choices are made"; and achievement is a result of the made choices (Kabeer 2001, 19-20).

Resources include tangible and intangible resources. Tangible resources encompass for instance organizations, equipment, finance, and so forth, while intangible resources consist of for example social networks, human capital, future imagination, knowledge, skills, and so on (Kabeer 2001, 20). Agency (process) is about the ability to define a goal and how to achieve it. So, agency is about the actualization of willingness or intention. Defining the goal and how to achieve it are very important because 'the goal' will indicate whether the implemented activities support gender equity and social justice or not. While 'how to achieve it' will show whether the implemented activities are rational and use a proper strategy to realize gender equity and social justice. In this respect, it should be noticed that agency meant here is not only related to observable actions such as conducting training on gender equity, bargain, and negotiation on a policy supposed to affect gender equity, criticizing any political and social structure affecting the inequitable relationship between men and women and so on but also concern with unobservable actions such as motivation of, the imagination of, and purpose of the implemented activities. Additionally, agency can be implemented in an individual and or a collective manner. Achievement (outcome) is the end of choice (Kabeer 2001, 21).

The measurement of resources is based on the variables of access, control, and self-determination. Access, control, and self-determination of the individual are aimed at maximally utilizing the resources to support the designed strategic life to be achieved (Kabeer 2001, 28-31). The meaning of access here is framed as a condition in which someone can access resources such as sources of education, social networks, funding agencies, and so on (March 1999, 34). The ability of access is determined by the individual ability and no external impediments blocking the actualization of individual ability (Nussbaum 2001, 84-85). Thus, those having the ability supposed to be free to access the resources, without any external interference. Meanwhile, the meaning of control is about the ability to decide the usage of the resources (March 1999, 34). The control over the resources 
is also related to externalities, for instance, whether the available social, cultural, and political structure discriminate one group of people and privilege the others. Being able to access and control resources will constitute self-determination, in which the empowered person decides not just how to utilize his or her resources but also what and whom the resources should be. So, the ability to decide the usage of resources is not quite enough, but the most important thing is what and whom the usage of resources will benefit (Kabeer 2001, 23-24).

The dimension of agency is measured by the role of the empowered men in influencing the decision-making process (Kabeer 2001, 34). The decisionmaking process here refers not only to policies of governments, but also any decision related to the strategic choice of life for instance what kind of training should be conducted to socialize and promote gender equity, whom will be the primary targets of the training, what content should be presented during the training and so forth. The role in the decision-making process will show whether the empowered men have a substantial and influential contribution to the decision made. The dimension of achievement is measured by whether the output and the outcome of any activity implemented by the empowered men diminishing or reinforcing the existing gender inequity (Kabeer 2001, 35).

The measurement of empowerment at the individual level is seemingly reliable and applicable in the context of this paper. This is because; first, empowerment is not just related to how to enhance individual ability to access and control resources, but is also related to how to control the agenda of policies (Parpart 2002, 6). Thus, empowerment focusing on the individual is likely to guarantee enhancement of individual abilities to control not only the institution and resources but also control the other people to commit their support in his or her agenda and activities. Second, every individual has basic power for instance willingness to express his or her voices and control others. However, the basic power just will be becoming potential of the individual, if he or she cannot actualize it or any external impediments blocking it. Therefore, empowered persons are expected to challenge any external impediments blocking every individual to express what he or she wants to (Nussbaum 2001, 84).

\section{Methods}

The methods to be used to generate the needed information to enrich the paper consist of three main ones; document review, direct observation, and interviews. The document review will be used to generate the information stemming from texts-based documents such as books, published articles in journals or newspapers, unpublished articles, reports, and so on. The documents have to be related to gender, masculinity, development, and social change. This is necessitated by the fact that this paper is about masculinity and development with a focus on the case of male Muslim leaders (Kiai) who have been mainstreaming women's empowerment in their work in Java Island, Indonesia. I will read and analyze the texts-based documents to extract the available information that might be useful to answer the development question explained earlier. To extract the 
available information in the text-based documents, I will read them and interpret their meanings including their socio-political contexts (Hodder 1994, 394). Additionally, I will reflect upon the substances of, both the meanings of and the results of interpretation over the documents to select which one is fit and not fit to answer the development question (Mason 2002, 115).

The direct observation is purely based on my experiences working together with male Muslim leaders in mainstreaming gender (Mason 2002, 84). The experiences likely will contribute to answering the development question. Before joining Sustainable International Development (SID) program at the Heller School, I have worked for several NGOs and research centers in Indonesia for instance Puan Amal Hayati (Islamic boarding school [pesantren]-based women crisis center) Jakarta, Indonesian National Commission on Violence Against Women Jakarta, and Research Center of Social Welfare at the University of Indonesia Jakarta. The NGOs and the research centers where I have worked mostly concern with the socialization and dissemination of Islam, gender equity, and women's rights. Their target groups are mostly Muslims both women and men across Indonesia.

The interviews were conducted to generate the needed information directly from male Muslim leaders who have been mainstreaming women's empowerment. I interviewed them the last summer, 2010 during the field visit to Indonesia. When interviewing them, I used semi-structured questions, as follows; I formulated the questions before the interviews. During the interviews, however, I was not bound rigidly with the formulated questions, so I could expand the questions with a follow-up question for additional information needed to answer the development question (Mason 2002, 62). The formulated questions were a guideline for me to conduct interviews with them. So, the interviews were intended to generate information from the analysis unit of the paper.

\section{Results and Discussion}

\section{Islam, Masculinity, and Male Muslim Leaders of Islamic Boarding Schools}

Masculinity as a social construction is also under questioning and critique in the Islamic context. This is because of the apparent sense of just a single variant of the identity of masculinity disseminated and spread throughout among Muslims. Men are usually described as powerful, strong, and virile persons. In contrast, women are described as weak, emotional, and dependent persons (Effendi 2010, 221-223). The normative framework of the single identity of masculinity in Islam is under question and critique because of its obvious contradiction. Usually, the identity of masculinity in Islam refers to fiqh (Islamic law) and Sufism (the mystical doctrine). Both are similarly extracted from the Quran (the holy book of Islam) and the Hadith. Fiqh, which is the basic reference and guidance of daily behavior of Muslims, generally emphasizes the sense of superiority of men over women and does not allow any sexual orientations except heterosexuality. Fiqh even justifies men's (the husband) perpetration of violence against women (the 
wife), if women are at any given time unable to comply with men's requests (Effendi 2010, 183, 224).

In contrast, Sufism emphasizes a spiritually equal relationship between men and women as well and among men themselves (Arberry 2002, 12). Within communities of Sufism, every human being, either women or men are treated equally and could reach the highest level of spirituality regardless of class, ethnicity, skin color, status, tribe, and so forth. Men and women reaching the highest level of spirituality have an equal opportunity to become the leaders of the communities in Sufism. Therefore, in the history of Sufism found a woman being a leader of one community of Sufism, namely Rabi'ah al-Adawiyah (d. Basra, Iraq, 185/801-802?) (Melchert 1996, 61). So, the contradiction of fiqh and Sufism regarding masculinity indicates how the gender role of men is socially constructed.

The identity of masculinity is plural and not single depending on where the social construction of masculinity takes place. The single identity of masculinity in Islam sustains a perception of the superiority of men over women. This perception remains intact because the identity of masculinity is an arena of contestation between the conservative perspective and progressive perspectives of masculinity in Islam. The conservative perspective emphasizes a single identity of masculinity, namely the superiority of men over women. Therefore, those who are inside of the conservative perspective condemn men who appear to resemble women, either in terms of their gestures and their sexual orientation (Monterescu $2006,129)$. While the progressive perspective emphasizes on plural identities of masculinity in Islam. Those who are inside of the progressive perspective acknowledge the plurality of masculinities depending on different methods of interpreting the normative framework of masculinity and different social contexts contributing to the construction of the identity of masculinity in Islam (Duderija $2010,127)$. The conservative perspective, nevertheless, has been embedded and internalized among Muslims for a long time, while the progressive perspective is a recent development coinciding with the emergence of masculinity studies in general. So the progressive perspective challenges the established conservative perspective of masculinity. Some of male Muslim leaders of Islamic boarding schools in Java following the progressive perspective.

Male Muslim leaders of Islamic boarding schools (pesantren) have real opportunities to get involved in gender equity. Just a few of them in Java Island, however, has been maximally and actively utilizing the real opportunities to pursue gender equity. Most of the other male Muslim leaders resist taking an active role in the promotion of gender equity or simply keep silent. The precedence of men's involvement in gender equity probably inspired recent male Muslim leaders in Java Island to be involved is traceable to Mohammad Dahlan and A. Aziz Dijar, two male leaders of the Indonesian largest traditionalist Muslim-based organization, namely the Awakening of Ulema (Nahdlatul 'Ulama, NU) in the 1930s. NU was established in Surabaya, East Java, 1926 by a group of male Muslim leaders; Hasyim Asj'ari (d.1947), Wahab Hasbullah (d. 1971), and Bisri Syamsuri (d. 1980). The purpose of NU was to devise ways on how to represent the socio-political and economic interests of Islamic boarding schools (pesantren) (Arnez 2010, 60). They 
both facilitated and encouraged the establishment of an organization of the women's movement within NU. Finally, their endeavor achieved the goal by the establishment of the women's organization, namely Muslimat NU in 1940.

Although at the time was not familiar with gender issues, the primary agenda of its initial existence was similar to gender issues, namely, how to eradicate illiteracy among women and how to achieve independence of Indonesia. Indonesia declared its independence from two and half centuries of Dutch colonialism on 17th August 1945. Both (Dahlan and Dijar) were the only leaders of NU who actively got involved in the establishment of Muslimat. They both actively lobbied the other leaders of NU who were all men to convince them that the existence of Muslimat would be profitable to NU. They both expected that if even the other leaders did not agree with the idea, at least they would not resist it and instead maintained silence. The other leaders had thought that at the time, it was not the right time for women to perform in public spaces such as in the organization of Muslimat, while they both had thought conversely that it was possible (Muslimat n.y., 1). So the involvement of male Muslim leaders in gender equity has precedence in the context of Javanese Muslims.

The sociopolitical dynamics of the global women's movement and men's involvement in gender equity in the 1970s-1990s affected Indonesia and most likely inspired male Muslim leaders in Java Island to get involved in gender equity as well. At the time, they questioned and challenged various issues of injustice affecting men and women. The issues ranged from a debt crisis, prostitution, health, reproductive rights, violence against women, environment, sexual orientation, identity, power relation, the feminization of poverty, trafficking, etcetera (Clatterbaugh 1997, 2-7; Edwards 2006, 2-3; Stienstra 2000, 63-68). The global women's movement and men's involvement in gender equity had positive impacts on Indonesia. First was the provision of constitutional and legal mechanisms to address any inequitable relationship between men and women such as the ratification of CEDAW (Convention on the Elimination of All Forms Against Women/CEDAW) in 1984, Indonesian Act no. 23, 2004 on Violence Against Women and so forth. The second was the establishment of women's agencies having authorities to address any gender issues. These include, for instance, the ministry of women's affairs (the 1970s - present), the National Commission on Violence Against Women (1998), faith or non-faith-based NGOs concerning gender issues, and so on. Lastly was the insistence or suggestion to involve various influential stakeholders such as men, women, community leaders, religious institutions and leaders, and so on, in pursuing gender equity (Effendi 2010, 212216; Hasyim 2010, 381-384; Muhammad 2004, 319-320). This insistence occurred in the 1990s and coincided with the fourth United Nations Conference on Women in Beijing, which officially encouraged men's involvement in gender equity.

The translation of gender terms into Islamic terms inspired and encouraged male Muslim leaders to get involved in gender equity. The translation was pioneered by an Islamic boarding schools-based NGO, namely Perhimpunan Pengembangan Pesantren dan Masyarakat (the Association of Islamic Boarding Schools and Community Development, P3M) in 1995 (Natsir 1997, 18). The 
reasons behind the translation were: firstly, Muslims in Indonesia in general and Java Island, in particular, were unfamiliar with gender terms hence the need to redefine them in the context of Islam. For instance, such terms as "gender equity" becomes al-musawa bayna al-mar'ah wa al-rajul; "good treatment over women" becomes al-mu'asyarah bi al-ma'roof; "justice" becomes 'adalah, and so on. Secondly, most Muslims often associated the usage of gender terms with Western ideas. So, it would trigger resistance because it was likely to be perceived as an intervention of Western countries into Indonesia and would thus destroy Islam from within (Effendi 2010, 213).

In Javanese Muslim, male Muslim leaders of Islamic boarding schools can be understood as a cultural broker (developed by Clifford Geertz 1960) and cultural mediator (developed by Hiroko Horikoshi 1976). The functions of cultural brokers are aimed at securing and maintaining the power and prestige of leadership in Islam toward Muslims (Geertz 1960, 230). As the mediators, the leaders in Islam do not select and filter the culture and the information will be coming into Muslims (Horikoshi 1976, 4), but occupy a key position as leaders and representatives of Muslims who have to fight for the interests of all Muslims. Furthermore, leaders in Islam are pioneers of social change and thus play a significant role in the creation of what is supposed to be fit and worthy to Muslims. The final decision of whether the proposed social-change, however, will be applied or not on the ground depends upon Muslims themselves. It is due to the fact that it is Muslims themselves who really know what they want to (Wahid 1987, xvii). Thus, the types of leadership encourage and facilitate men's involvement in pursuing gender equity in such mediatory and facilitative ways.

\section{Resources, Agency, and Achievement in Promoting Gender Equity}

Why do just a few male Muslim leaders choose to get involved in gender equity? The answers lie with the fact that they most likely have a different understanding, perception, and subjective intention over the existing cultural practices in Java Island and how gender would impact these (Kabeer 2001, 25; Smith 2001, 155). They also seem to have different choices of life that they want to prioritize. Indeed, they have similar experiences of life. They have been experiencing and living in the context of patriarchal and paternalistic cultures of Java Island, the political systems of Indonesia, and Islamic traditions in Java Island, mostly privileging and favoring the superiority of men over women and other gender groups. They understand and perceive, however, the cultural practices differently. Those not choosing and involving in gender equity understand and perceive the cultural practices as fixed, given, and should be taken for granted (Ramli 2004, 1; Taftazani 2007, 67). Furthermore, they understand and perceive the existing cultural practices as 'doxa', which are unquestioned, undiscussed, natural, and should be reproduced over time (Kabeer 2001, 25-26; Smith 2001, 157-158). This is intended to maintain the continuation of the existing cultural practices and the purity of Islamic teachings formulated in the medieval age of Islam (1250-1800 CE). In contrast, those choosing and involving in gender equity understand and perceive the existing cultural practices as social constructions, 
which are questionable, discussable, changeable, and dynamic depending on their social contexts (Effendi 2010, 214; Natsir 1997, 9-11). They analyze and select the cultural practices; which one truly refers to Islam and which one is Islamic thought. The continuation of the former should be kept going on, but not the latter. The true Islam propagating peace and justice will become perennial values over time. Islamic thought can change continuously depending on the social contexts (pers. comm., July 20, 2010).

Their different choices of life are about whether they deliberately want to analyze critically the existing cultural practices and pursue gender equity or not. Those who deliberately preserve the existing cultural practices, do not want to pursue gender equity. So, their choices of life remain intact, with no change at all. It is already available choices of life, namely, equitable relationships between men and women. On contrary, those who criticize the existing cultural practices as to get involved in gender equity have made strategic choices in life. It is called strategic choices of life because previously they denied and did not know what gender equity was. They started involving in gender equity in the 1990s and 2000s. Some of them began involving in gender equity in 1995 facilitated by P3M, while the rest started involving in gender equity in 2004 facilitated by Rahima and Puan Amal Hayati, two Islamic-based NGOs concerning Islam, gender equity, and violence against women, which are located in Jakarta. Therefore, based on their strategic choice of life, they are considered as "empowered persons". Empowerment, as we know, is about enhancing people's freedom of choices and actions to guide their own life (Kabeer 2001, 19; Narayan 2005, 4).

Three dimensions should be taken into consideration in assessing their empowerment, including resources, agency, and achievement (Kabeer 2001, 20). First, the measurement of intangible and tangible resources refers to whether they can access, control, and determine the usage of the resources that they have (Kabeer 2001, 30-31; March 1999, 34). Those who have been choosing and involving in gender equity have both resources and can access, control, and determine their usage. The intangible resources that they have include education, self-motivation, social capital, and etcetera. Their formal education varies since both of them graduated from colleges; Islamic college and medical college, while the others just graduated from senior high school. They are, however, knowledgeable in Islam and their knowledge of gender issues was obtained from pieces of training and workshops on Islam and gender held by Islamic-based NGOs concerning gender issues and Islam such as P3M, Rahima, Puan Amal Hayati, and so forth ranging from 1995-2006. So their knowledge of gender issues was the result of facilitation by the NGOs.

After participating in such pieces of training and workshops, they reflected on the cultural practices of the relationship between men and women and applied the knowledge and skills learned within their community. They found unequal relationships, for example where mostly women become victims of violence perpetrated by men. They also found out that women had no bargain toward men. The unequal relationship between men and women could occur within their families in particular or within the communities in general. Based on 
the results of their reflection, they strongly wanted to transform such unequal to equal relationships. According to them, "the unequal relationships do not come from Islam, because the true Islam propagates justice and peace" (pers. comm., July $10,15,16,20,2010)$. The social capital that they have supports their willingness to disseminate and propagate justice and gender equity. The social capital meant here is about "social network and the norms of reciprocity and trustworthiness that arise from them" (Hooghe 2003, 4). The social capital that they have is not only in a horizontal way, namely, their network with their communities and the broader societies but also in a vertical way, namely their network with Indonesian governments at all levels. They utilize their social capital to mobilize people in supporting their willingness for the realization of gender equity.

The tangible resources that they have to encompass, based on my experiences, Islamic boarding schools that they lead, NGOs, and women crisis centers (WCC) that they are involved with by way of channeling support of funding either coming from international or domestic agencies and so forth. The tangible resources that they have to arise out of the influence they have through their willingness to disseminate and propagate justices in the community. This is because tangible resources, for instance, Islamic boarding schools, NGOs, and WCC can influence and change gender-biased cultural practices. Islamic boarding schools in the context of Java Island are the most respectful and powerful institutions. It becomes the center of knowledge reproduction in Islam and power judging whether the existing cultural practices are true or not (Dhofier 1983, 56). Additionally, NGOs, where they engage, can facilitate information flows coming from outside and encouraging social change within their communities. While WCC can influence and change the mindset and behavior of Muslims regarding violence against women. The tangible resources, in the hand of the four male Muslim leaders, are maximally utilized to support the realization of gender equity.

Secondly, the measurement of agency can be seen in their involvement in policy decision-making processes either at governmental or at societal levels. Their involvement at the governmental level concerns their participation and influence in any policy made by governments which are likely to affect equitable relationships between men and women (Kabeer 2001, 34), while their involvement at the society level concerns their participation and influence in any policy made by community leaders which are likely to affect to the entire community (pers. comm., July 20, 2010). When participating and influencing in the decision-making process of the policies of governments either at national or at sub-national levels, they usually align with the NGOs advocating such policies. These alliances are not permanent but are maintained on an ad-hoc basis depending on the issues at hand. Just one of them, however, engages in the alliances at national and sub-national levels, while the others engage in the alliances at sub-national levels. Even, one of them has been elected as a commissioner of the National Commission on Violence against Women for two terms (2007-2010 and 2010-2013).

At the societal level, they, as part of community leaders, strongly influence any policy made and daily behaviors of their community. Their influences are 
mostly through pieces of training on gender and Islam, lobbies to convince the other male Muslim leaders and ask them to engage in gender equity, and the provision of alternative understanding through a reinterpretation of the Quran as the basic reference of Islamic teachings. It is because the existing Islamic teachings do not reflect the substantial values of Islam, namely, justice and peace. As elaborated earlier, the existing Islamic teachings mostly propagate the superiority of men over women. The method of their reinterpretation consists of recognition of the main purpose of Islamic teachings; analysis of socio-historical aspects of any verse in the Quran; linguistic analysis of the Quran texts; identification of the causality of the Quran verses; and critical analysis of the Hadiths' transmission (Muhammad 2004, 187-188, 333-334). Just two of them, however, have enough knowledge to reinterpret the Quran, while the others, actively disseminate the results of the reinterpretation. These agencies are intended to achieve their main purpose, i.e. the realization of gender equity

Thirdly, the measurement of achievements takes into account whether what they have done reinforces or diminishes the existing gender-biased cultural practices (Kabeer 2001, 35). There are three factors, as mentioned earlier, contributing to gender-biased cultural practices in Java Island. These are Javanese culture, Islamic teachings, and the policies of governments. The outcome and output of what they have done completely diminish the existing gender-biased cultural practices. Regarding the policies of governments at the national level are to be seen in the passing of Act no. 23, 2004 on Violence Against Women, Act no. 21, 2007 on Anti-Trafficking, Act no. 2, 2008 on political parties requiring 10 percent of women at national and sub-national legislatures, and so forth. While at subnational levels were evidenced by the passing of the district law (peraturan daerah) no. 9, 2009 on Reproductive Health (Tasikmalaya), and the district law no. 4, 2008 on Violence Against Women (Jember), and the ongoing process of the district law on Violence Against Women (Indramayu) (pers. comm., July 10, 15, 16, 20, 2010).

Related to Islamic teachings, one of their achievements, the reinterpretation of the existing Islamic teachings, was the study of a fiqh book, called Kitab Syarh 'Uqud al Lujjain fi Bayan Huquq al Zaujain (notes on the mutual responsibility concerning the clarification of the rights of a spouse) written by Muhammad bin 'Umar Nawawi al Jawi al Bantani al Syafi'i (1813-98). The book has greatly affected the relationships between men and women (spouse) in Javanese Muslims (Doorn-Harder 2006, 167). The result of the study was under the title New Type of Relationships of Spouse and published jointly by the publisher of LKiS, Yogyakarta, and FK3, Jakarta in 2003. Lastly, in terms of culture, they have been raising awareness of Javanese Muslims on gender equity and violence against women as criminality. Based on data of National Commission on Violence Against Women 2009, violence against women in Java Island was the highest of the other Islands as follows 123,774 (Java), 8,987 (Sumatera), 4,632 (Borneo), 2,301 (Sulawesi), 2,126 (Nusa Tenggara), 858 (Bali), 347 (Moluccas), and 281 (Papua) (Khusnaeny 2009, 9-10). The high violence against women in Java island was because Javanese people have been aware that violence against women is criminal and should be filed to a women crisis center or police directly. 
Transformation of their involvement in gender equity to the other male Muslim leaders is very needed and urgent. It is because Male Muslim leaders are influential stakeholders who can accelerate the realization of gender equity in Java Island. The transformation should be through ongoing dialogues, which probably will take a long time (UNFPA 2004, 22). During the dialogues, the process should first, be the presentation of the facts of injustice grievances experienced by women and men followed by Islamic arguments propagating justice and peace between men and women.

\section{Conclusion}

The involvement of male Muslim leaders in gender equity accelerates the realization of gender equity and guarantees equitable social development. It is because they directly challenge the root causes of gender inequity leading to the discrimination of women in all sectors of development. Additionally, they use the appropriate strategies in line with the doctrine and faith of Islam. First, the root causes of gender inequity in the context of Java Island that these leaders target include culture, gender-biased policies of the government, and tenets of Islamic teachings that seem to engender disagreements over gender relations. Thus, they do not just tackle the symptoms of gender inequity, but go to the root causes as a way of seeking lasting transformation in respect of gender equity and the empowerment of women. If they restricted their intervention only to the symptoms of gender inequity, they would miss a direct engagement with the selfgenerating socio-cultural system that reproduces gender inequity. As such gender inequity would be going on despite their intervention. It is akin to just providing medicine to heal the problems of reproductive health of women while ignoring the structural socio-economic roots to the problems of reproductive health, an action that simply ensures that the problems remain intact and unresolved. The primary causes of reproductive health problems will remain intact since the inequitable relationships between men and women will remain untouched. Therefore, when implementing development initiatives, the root cause of the development's problem must of necessity be addressed and tackled properly.

Second, the appropriate strategies deployed by the Islamic leaders in their pursuit of gender equity in sustainable social development encompass the usage of influential educational institutions among Javanese Muslims and the usage of religion (Islam) as the basic point of anchorage for gender inequity. Firstly, the influential educational institutions, that they use to pursue gender equity and equitable social development, are Islamic boarding schools (pesantren), which are the oldest educational institutions in Java Island. The Islamic boarding schools become influential institutions because their leaders are a source of power and authority in the community. Muslims living around Islamic boarding schools or beyond will readily comply with what the leaders are saying. They become trustworthy under their leadership and knowledge. They are knowledgeable not only in terms of Islam but also the other social issues. The leaders become not only teachers and preachers but also counselors and advisers of their communities. 
Male Muslim leaders becoming the object of this case study are part of the leadership of Islamic boarding schools, a position that bestows upon them the capacity to affect the lives of the widest spectrum of society.

Thirdly, they use religious arguments to pursue gender equity, thus bringing home the message in a religious package acceptable to most people and therefore most likely to be followed. The usage of the religious arguments is intended to minimize any resistance likely to come from the other Muslim leaders who maintain that the language and the message of gender are not familiar to them and are usually associated with Western ideas which they argue, aims at destroying Islam from within. Male Muslim leaders who pursue gender equity use religious arguments to convince those, other male Muslim leaders still reluctant to join efforts in promoting gender equity. Since, the ideas of gender equity do not violate Islamic teachings and will not harm but reinforce their existing power and authority, as ordained in Islam, these efforts are likely to guarantee equal partnership in development with all stakeholders, including women, and will thus promote and propagate justice and peace as substantive values of Islam. Therefore, the success or failure of development's implementation requires appropriate strategies drawn from within existing systems and institutions to appear less threatening while being highly effective in implementing initiatives aimed at promoting equity and social justice.

The implications of male Muslim leaders' involvement in pursuing gender equity are inter alia; it can be a model of men's involvement in gender equity, it can inspire development practitioners to pay attention to entry strategies for effectively implementing interventions that are otherwise deemed culturally and religiously sensitive. This case demonstrates just how an institution considered inimical to transformation in gender terms can be turned around to utilize the resources within to positively contribute to the success of development's implementation. The involvement of male Muslim leaders can be the model of men's involvement in gender equity because up to now, only a few men are actively engaged in gender equity and there is a need to expand their participation in this area. Most of them resist or do not want to support any effort aiming at pursuing gender equity because of their erroneous belief that gender equity favors only women in a win-lose situation where men end up being disadvantaged. This case demonstrates that in fact, the problems of gender inequity will harm not only women but also men, and thus the involvement of men is good not just for women but all men as well in a win-win situation. Although their involvement can be the model, however, the men's involvement in gender equity should be based on the local context where the implementation of development takes place.[]

\section{Acknowledgements}

This article is adapted from my master thesis which submitted for the degree of Master of Arts in Sustainable International Development at the Heller School for Social Policy and Management, Brandeis University, United States, 2011. 


\section{References}

Arberry, Arthur John. 2002. Sufism: An Account of the Mystics of Islam. New York: Dover Publication Inc.

Arnez, Monica. 2010. "Empowering Women Through Islam: Fatayat NU Between Tradition and Change." Journal of Islamic Studies 21, no. 1: 59-88.

Clatterbaugh, Kenneth. 1997. Contemporary Perspectives on Masculinity: Men, Women, and Politics in Modern Society. Boulder, Colorado: Westview Press.

Connell, R. W. 2005. Masculinities. Berkeley, Los Angeles: University of California Press.

Dhofier, Zamakhsyari. 1983. Tradisi Pesantren: Studi Tentang Pandangan Hidup Kyai (Islamic Boarding School Tradition: Study of Kia's View). Jakarta: LP3ES.

Doorn-Harder, Pieternella van. 2006. Women Shaping Islam: Reading the Quran in Indonesia. Urbana and Chicago: University of Illinois Press.

Duderija, A. 2010. "Progressive Muslims - Defining and Delineating Identities and Ways of Being a Muslim." Journal of Muslim Minority Affairs 30, no. 1: 127-136.

Edwards, Tim. 2006. Cultures of Masculinity. New York: Routledge.

Effendi, Djohan. (2010). Pembaharuan Tanpa Membongkar Tradisi (Renewal without Dismantling Tradition). Jakarta: Kompas.

Geertz, Clifford. 1960. "The Javanese Kijaji: The Changing Role of a Cultural Broker." Comparative Studies in Society and History 2, no. 2: 228-249.

Geertz, Clifford. 1960. The Religion of Java. Chicago: The University of Chicago Press.

Greig, Alan, Michael Kimmel, and James Lang. 2000. Men, Masculinities, and Development Monograph Series of Gender in Development. New York: United Nation.

Hodder, Ian. 1994. "The Interpreation of Documents and Material Culture". In Hanbook of Qualitaive Research, edited by N. K. Denzin and Y. S. Lincoln. Thousand Oaks, California: SAGE Publications.

Hooghe, Marc, and Dietlind Stolle. 2003. "Introduction: Generating Social Capital." In Generating Social Capital: Civil Society and Institutions in Comparative Perspective, edited by Marc Hooghe and Dietlind Stolle, 1-18. New York: Palgrave Macmillan. 
Horikoshi, Hiroko. 1976. "A Traditional Leader in a Time of Change: the Kijaji and Ulema in West Java.” PhD Diss., University of Illinois, Urbama.

Howson, Richard. 2006. Challenging Hegemonic Masculinity. New York: Routledge.

Kabeer, Naila. 2001. "Resources, Agency, Achievements: Reflections on the Measurement of Women's Empowerment." In Discussing Women's Empowerment: Theory and Practice, edited by Anne Sisask, 17-57. Stockholm: Sida.

Kabeer, Naila. 2007. "Marriage, Motherhood and Masculinity in the Global Economy: Reconfigurations of Personal and Economic Life." IDS Working Paper 290, The Institute of Development Studies.

Khusnaeny, Asmau'ul et al. 2009. Annual Notes on Violence Against Women. Jakarta: National Commission on Violence Against Women.

Kimmel, Michael S., Jeff Hearn, and Robert W. Connell. 2005. "Introduction." In Handbook of Studies on Men and Masculinities, edited by Michael S. Kimmel, Jeff Hearn, and Robert W. Connell, 1-12. Thousand Oaks, California: Sage Publications.

March, Candida, Ines Smyth, and Maitrayee Mukhopadhyay. 1999. A Guide to Gender Analysis Frameworks. London: Oxfam.

Mason, Jennifer. 2002. Qualitative Researching. Thousand Oaks, California: SAGE Publication.

Melchert, Christopher. 1996. "The Transition from Asceticism to Mysticism at the Middle of the Ninth Century C.E." Studia Islamica 83: 51-70.

Monterescu, Daniel. 2006. "Stranger Masculinities: Gender and Politics in a Palestenian-Israeli 'Third Space'." In Islamic Masculinities, edited by L. Ouzgane, 123-142. New York: Zed Books.

Muhammad, Husen. 2004. Islam Agama Ramah Perempuan (Islam is WomenFriendly Religion. Yogyakarta: Fahmina Institute-LKiS.

Muslimat. n.d.. "Sejarah Muslimat NU (History of Muslimat NU)." nu.or.id, Accessed March 20. http://www.muslimatnu.or.id/index.php?option=com_content\&view=article \&id=67\&Itemid=56 website:

Narayan, Deepa. 2005. “Conceptual Framework and Methodological Challenges.” In Measuring Empowerment: Cross-Disciplinary Perspectives, edited by Deepa Narayan, 1-38. Washington, DC: The World Bank. 
Nations, United. 1996. "Report of the Fourth World Conference on Women." Beijing, 4 - 15 September 1995 New York United Nations.

Natsir, Lies Marcoes, and Syafiq Hasyim. 1997. P3M dan Fiqh an-Nisa' untuk penguatan hak-hak reproduksi perempuan (P3M and Fiqh an-Nisa' for Strengthening Women's Reproductive Rights: P3M-Jakarta.

Nussbaum, Martha C., 2001. Women and Human Development: The Capabilities Approach. New York: Cambridge University Press.

Nyerere, Julius. 2007. "Masculinity." In International Encyclopedia of the Social Sciences, 2nd edition, edited by William A. Darity Jr., Vol. 5. Farmington Hill, Michigan: Gale Cengage Learning.

Parpart, Jane L., Shirin M. Rai, and Kathleen A. Staudt. 2002. "Rethinking Em(power)ment, Gender and Development." In Rethinking Empowerment: Gender and Development in a Global/local World, edited by Jane L. Parpart, Shirin M. Rai, Kathleen A. Staudt, 3-21. New York: Routledge and Centre for The Study of Globalization and Regionalization.

Pini, Barbara. 2008. Masculinities and Management in Agricultural Organizations Worldwide. Burlington, VT: Ashgate.

Ramli, M. Idrus. 2004. "Akar dan Karakteristik Pemikiran FK3: Pengantar Editor (Roots and Characteristics of FK3 Thought: An Editor's Introduction)." In Menguak Kebatilan dan Kebohongan Sekte FK3 (Revealing the falsehood and lies of FK3 Sect), edited by M. Idrus Ramli, 1-24. Pasuruan: RMI.

Ruxton, Sandy. 2004. "Introduction." In Gender Equity and Men: Learning from Practice, edited by S. Ruxton, 1-18. Oxford, UK: Oxfam GB.

Siraj, Asifa. 2006. “On Being Homosexual and Muslim: Conflicts and Challenges.” In Islamic Masculinities, edited by Lahoucine Ouzgane and Michael Kimmel, 202216. New York: Zed Books.

Smith, Adam T.. 2001. "The Limitations of Doxa: Agency and Subjectivity from an Archaeological Point of View." Journal of Social Archaeology 1, no. 2:155-171.

Stienstra, Deborah. 2000. "Making Global Connections among Women, 1970-1999." In Global Social Movement, edited by R. Cohen and S. M. Rai, 62-82. New Jersey: the Athlone Press

Taftazani. 2007. "Pandangan Pesantren tentang Kedudukan Perempuan (Pesantren Views on the Status of Women)." In Budaya Damai Komunitas Pesantren (Peaceful Culture of Pesantren Community), edited by B. Sholeh, 65-73. Jakarta: LP3ES. 
UNFPA. 2004. Working from Within: Cultural Sensitive Approaches in UNFPA Programming. New York: UNFPA.

Wahid, Abdurrahman. 1987. "Benarkah Kyai Membawa Perubahan Sosial?: Sebuah Pengantar (Is It Right, Male Muslim Leaders Create Social Change?: An Introduction)." In Kyai dan Perubahan Sosial (Male Muslim Leaders and Social Chnage), edited by H. Horikoshi, xi-xxii. Jakarta: P3M.

Young, K. 1997. "Gender and Development." In The Women, Gender and Development: Reader, edited by Nalini Visvanathan, Lynn Duggan, Nan Wiegersma, and Laurie Nisonoff, 51-54. Atlantic Highlands, NJ: Zed Books LTD.

\section{Author Biography}

Edi Hayat is an expert staff at Commission VIII of the House of Representatives of the Republic of Indonesia. He completed a Masters of Arts in Sustainable International Development at the Heller School for Social Policy and Management, Brandeis University, United States. His research interests encompass gender and development, masculinity, and social policy.

Email: edihayat10@gmail.com 